\title{
Energiapolitika: minden területi szinten
}

\section{Energy policy: on all territorial levels}

\author{
CSÁK LÁSZLÓ
}

CSÁK László: társult egyetemi oktató, Babeș-Bolyai Tudományegyetem, Sepsiszentgyörgy, Románia; igazgató, Planificatio Kft., Románia; laszlo.csak@gmail.com

KULCSSZAVAK: energiapolitika, területi tervezés, megújuló energia, irányítás

ABSZTRAKT: Az energiapolitikát és a területpolitikát egészen a legutóbbi időkig joggal kezelték elkülönülten, hiszen az energiatermelés jellemzően néhány centrumban összpontosult. Így különösen az elektromos energia rendszerei, melyek országos szinten szerveződtek, és néhány, sokszáz megawatt teljesítményű erőműben állították elő az áramot, ráadásul az előállításhoz szükséges szén vagy gáz is térben jól körülhatárolható, viszonylag kis területről származott. A helyzet azonban gyökeresen megváltozott, amennyiben a megújuló energiát hasznosító technológiák kifejezetten helyhez kötöttek, helyiek vagy térségiek, adott esetben ennek megfelelően regionális szinten értelmezhetők. A hálózatok decentralizáltak, de immár nemcsak a fogyasztás, hanem a termelés szempontjából is. Az energiatermelés lehetősége a fosszilis energiahordozókkal nem rendelkező területek számára is megnyílik, ugyanakkor ezt jelenleg sem a szabályozási, sem a tervezési gyakorlat nem veszi figyelembe. A területpolitikával kapcsolatos vizsgálatok közül jelen tanulmányban az ESPON-kutatásokat tekintettem át, amelynek alapján nyilvánvaló, hogy a területi szakma nem szentel megfelelő figyelmet az energia kérdésének. Az energiapolitika azonban területi kérdéssé vált, amely kifejezetten indokolttá teszi, hogy területpolitikai eljárásokba integráljuk.

László CSÁK: guest lecturer, Babeș-Bolyai University, Sfântu Gheorghe, Romania; director, Planificatio S.R.L., Romania; laszlo.csak@gmail.com

KEYWORDS: energy policy, spatial planning, renewables, governance

ABSTRACT: Global, regional and local energy systems are changing: centralised power grids, based on multi-megawatt generation plants are shifting to decentralised, polycentric systems, where the end user may become also a producer of electricity. Even farmers became part of the energy system as producers, processing agricultural by-products to generate bio-fuels. Local communities are planning investments in wind farms, photovoltaic parks and micro-hydro-power stations.

This raises the question of energy policy governance: Should it be centralised-hierarchical as it still is in many countries, and used to be characteristic everywhere, or is there a need for switching to a multi-level governance approach? There are participative and collaborative patterns of action emerging on the ground in local communities, city regions and neighbourhoods.

Unfortunately, the spatial planning discipline only partly recognised the importance of energy issues. As a consequence some references on energy policy and its spatial implication in a series of ESPON reports are collected in this study. This is the context of the present paper which

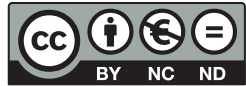


focuses on identifying the possible outcomes of integrating energy issues into spatial planning practice. Most of the results seem to be useful in relation to all types of energy generation. The results show that spatial planning is a suitable field where energy planning can find its role and context, due to its large experience in participative, collaborative planning. Spatial planning can gain additional social acceptance by integrating energy and renewable energy issues in its discourse. Environment, cultural heritage and regional capital have already been seen as major topics to be discussed during the planning process. Concerns about energy generation and distribution should be included.

\section{Bevezetés}

Korunkban az energia kérdése egyre égetőbbé válik, amit önmagában egyértelműen csak üdvözölni lehet. Sőt, azt mondhatnánk, hogy a mostani teendők súlyossága talán jóval kisebb lenne, ha évekkel, évtizedekkel korábban következik be a szemléletváltás. Szemléletváltásról beszélhetünk, ez egyértelmű, ha nem is forradalmi változásról: a hosszú távú trendelemzések szerint növekvő energiaárak miatt fontos kérdéssé vált az energiaszegénység, a bevett technológiák körébe tartoznak a megújuló energiák, jelentős szakpolitikai figyelem övezi a szektort, több tagállamban egyértelmü civil részvétellel alakul a témakör jövője, a hagyományos technológiák várhatóan háttérbe szorulnak az elkövetkező évtizedekben (Boyle et al. 2012; Everett et al. 2012).

Miért lehet ez azonban érdekes a területi tervezés, a regionális tanulmányok szemszögéből? Elsősorban az energiarendszer átalakulásának jellege és irányultsága miatt. A trend egyértelmű az elektromos hálózatok esetében, amennyiben egy-egy tagállam nem hoz olyan politikai döntést, amely a centralizált rendszert helyezi előtérbe. A továbbiakban elsősorban az elektromos áram előállítására vonatkozó példákra hivatkozunk, ugyanakkor a következtetéseink, bizonyos megszorításokkal, más energiatermelési módok esetében is helytállóak lehetnek.

Ha csak a korábbi időszakot vizsgáljuk, a termelés - a méretgazdaságosság elvének megfelelően - többszáz megawatt teljesítményű erőművekben valósult meg, legyen szó szén, földgáz, vízi- vagy atomerőművekről (Everett et al. 2012; Gasch, Twele 2012). Ezek az erőművek - a szállítási veszteségeket csökkentendő - a hálózatra magas vagy nagyon magas feszültségű szinten csatlakoztak. A hálózat tehát polarizált volt: egyik póluson a kevés számú nagy termelővel, a másikon pedig a jóval több ipari fogyasztóval, valamint az elosztási hálózatra jellemzően a $230 \mathrm{~V}$ szinten csatlakozó lakossággal. A fogyasztók világa - beleértve a lehetőségeket is - homogén, azaz jellemzően az határozza meg egy terület fogyasztását, hogy mennyire energiaintenzív az ott folyó tevékenység. És csak olyan helyeken okozna nehézséget a többletáramigény kielégítése, ahol az amúgy sem merül fel, így a magashegyi, periferikus, elszigetelt helyeken (Riegler 2004). 
Ezzel szemben a hálózati minta egészében megváltozott, két okból is. Egyrészt a fogyasztók potenciális termelőkké váltak. Hogyan lehetséges ez? Egy gyár lapos teteje kiválóan alkalmas fotovoltaikus rendszer telepítésére, mint ahogy egy déli tájolású tető a magánház tulajdonosát is arra vezetheti, hogy a megváltozott energiaszemlélet jegyében maga is egy termelő egységet szereljen fel. A hálózatnak ezen a szintjén nincs magasfeszültség, az elosztási hálózat veszi át a megtermelt áramot a lakótól, az ipari vagy kereskedelmi fogyasztó pedig amúgy is rendelkezik saját transzformátorral, azaz eleve megoldott a magasabb feszültségen történő betáplálás.

Másrészt jóval kisebb méretezésüek a szélturbinák (Gasch, Twele 2012), a kis vízierőmüvek, a napelemparkok: néhány kilowattól néhány tucat megawattig terjedő tartományban müködnek, térben elszórtak (Boyle et al. 2012). A napelemparkok esetében az erőforrás mindenhol hozzáférhető, tehát csak a telek ára és az engedélyezés lehetősége befolyásolja első közelítésben a helyszín kijelölését. A méret tekintetében nincs értelmezhető felső korlátja egy fotovoltaikus parknak, azonban egy-egy beruházás költségigénye miatt jellemzően néhány hektár területet hasznosítanak. A területi szempontot az engedélyezési feltételek révén megjelenő környezetvédelmi, agrár-, vagy esztétikai követelmények jelentik, valamint a közelben hozzáférhető középfeszültségü hálózati csatlakozás. Az utóbbi Európában jellemzően igen sürü hálózatot jelent, amely nem korlátozza a technológia elterjedését (Everett et al. 2012).

A szél, a víz vagy a biomassza térben jól meghatározható minta szerint alkalmas vagy sem a hasznosításra (Simon, Wiegmann 2009). A szél esetében figyelembe kell venni a viszonylag folyamatos müködést lehetővé tevő sebességet, irányt, valamint más szempontokat is, például a vándormadarak vonulási útvonalát vagy technikai szempontok miatt az alacsony turbulenciát (települések, hegyek, épületek ezen okból jellemzően nem alkalmasak erre a célra) (Gash, Twele 2012).

A víz esetében két jellemző irány figyelhető meg, mivel a nagy erőmüvek már korábban megépültek Európában: egyrészt az ún. pumped-hydro rendszerek, amelyek a hálózat ideális „egyensúlyozói”. Működési elvük, hogy olcsó, jellemzően a nagykereskedelmi piacról beszerzett áramot használva a víz potenciális energiáját növelik, azaz magasabbra szivattyúzzák a vizet, majd amikor nagy a fogyasztás és az áram drága, a potenciális energiát mechanikai energia közvetítésével elektromos energiává alakítják vissza. Jellegükből adódóan az ilyen rendszerek nagyok, több megawatt vagy gigawatt méretezésüek, és nem is tartoznak a megújuló energia körébe, mivel a hálózatból veszik az áramot. Másrészt megjelentek a micro-hydro rendszerek is, amelyek a kisebb, nagy esésü és megfelelő hozamú patakokat fogják be az áramtermelésbe. A nagy erőművek Európában már korábban megépültek, kivéve azokat a lehetőségeket, ahol hosszan tartó politikai vagy civil ellenállás akadályozta meg a folyók ilyen hasznosítását.

A biomassza (energianövények, fahulladék, szerves hulladék, mezőgazdasági melléktermékek, szennyvíziszap felhasználásával) térben koncentrált, de jóval 
kisebb kapacitással, mint a hagyományos erőművek, mivel kisebb egységnyi tömegre jutó energiatartalma miatt a nagy távolságra való szállítás nem hatékony sem pénzügyi, sem energiahatékonysági szempontból (Sterner, Fritsche 2011). Mivel a biomassza energiatartalma jellemzően jóval alacsonyabb, mint a fosszilis energiahordozóké, érzékenyebb a szállításra: 15-75 km a jellemző szállíthatósági határ, az adott biomassza tulajdonságainak (energiatartalom, súly, sűrüség, méret, a felhasználás módja stb.) függvényében (Simon, Wiegmann 2009).

Összefoglalva: a korábbi rendszert szállítási szinten betáplált, többszáz megawatt méretezésű, kis számosságú erőmű határozta meg, ezzel szemben az új rendszerek alacsonyabb feszültségü hálózati szinteken jelennek meg. Méretük, a működésük folyamatossága, technológiai megoldásaik különbözőek. Sőt, időben is változó módon és a térben szétszórtan jelennek meg, sok esetben elöre nem látható mintát követve, amit a háztartási áramtermelés esete is mutat (Sovacool 2011).

\section{Decentralizáció az energiapolitikában?}

Hol születnek az energiát illető döntések a hagyományos gazdasági rendszerben? Jellemzően állami szinten, hiszen egy-egy sokszáz megawattos erőmű milliárd eurós nagyságrendű beruházást feltételez, óriási területi hatással (Florini, Sovacool 2009). A néhány centrumban összpontosított termelés esetén ideális rendszer a központilag tervezett, azonban illeszkedik-e ez a megoldás az új körülményekhez? Kétszeresen is nem a válasz: a „nagy termelős” logika mindenképpen problémaként tekint a kisebb rendszerekre, amelyek müködése kiszámíthatatlan, mivel a napenergiás, valamint a szélenergiás rendszereknek nagy az időjárási kitettsége, tehát a hagyományos hálózati szemléletű gazdálkodás nem tenné lehetővé a megújuló energiák hasznosítását az áramtermelésben. A megszokott engedélyezési, tervezési eljárás is értelmetlen a megújuló rendszerek helyi és regionális szintjén, mivel a nagy erőművi rendszerekre kidolgozott eljárások túlzott bürokratikus akadályt jelentenének az új kis és mikrorendszerek elterjedésében.

A megújuló energiák hasznosítása minden eddiginél fontosabbá teszi az egyes tagállamok hálózatainak összekapcsolását, mivel az alacsonyabb beruházási szinttel elérhető fotovoltaikus és szélturbinás rendszerek időben változó, kevésbé előrejelezheto, változékony jellegű erőforrással dolgoznak (elég egy kis felhő, és a napelem máris 15-20\%-kal kevesebb áramot termel) (Boyle et al. 2012). Azaz létrejöhetne egy európai, sőt nemzetközi tervezési, irányítási és beruházási szint az országos rendszerek fölött. Miért lenne megoldás a tagállamok feletti területi szint? Azért, mert térben szétszórt sok kis termelőről van szó, a szétszórtság és a nagy számosság előnnyé válhatna. Ha össze lehetne kapcsolni a különböző szintű hálózatokat, akkor viszonylag kiegyensúlyozott rendszer jö- 
hetne létre. Az ilyen együttmüködések már megjelentek az EU dokumentumaiban is, sőt, a tagállamok közti együttműködések e terveket már megelőzték Észak-Európában, kihasználva a tengerek nyújtotta áramtermelési lehetőségeket (a hullámok, az áramlások, az árapály és a szél energiájának hasznosítása) (Boyle et al. 2012; Delina 2012).

Kérdés, hogy energia szempontjából önellátóvá tehetö-e a helyi vagy a regionális szint? A német vizsgálatok azt mutatták, hogy megoldható akár a településszintü energia-önellátás, azonban aligha nevezhető fenntarthatónak az ilyen megoldás (Jenssen et al. 2014). A tapasztalatok szerint az alacsonyabb regionális szintű energiaellátás túlságosan költséges. Túl magas árat jelent, ha túl alacsony szinten törekszünk az önellátásra. Megéri-e például egy házat csak napenergiával müködtetni? Pénzügyi szempontból semmiképp, mivel nemcsak a kollektorokat és a napelemeket kell megvásárolni, hanem nagy és drága akkumulátorokat is, hiszen éjjel is használjuk az áramot. Abszurddá válik az ilyen „önellátás”, ha figyelembe vesszük, hogy a megtermelt áram a hálózatba betáplálható, azaz a hálózat virtuális akkumulátorként működik. Ráadásul ez nem igényel új beruházást, hiszen gyakorlatilag mindenhol hozzáférhető robusztus infrastruktúráról van szó.

Kisebb rendszerek regionális szintjén is nagy a valószínűsége, hogy egy pénzügyi megtérülési vizsgálatot nem állna ki az áramönellátás kérdése: több fogyasztó esetén saját hálózatot kell kiépíteni, nagyobb fogyasztás és távolságok esetén (néhány km-t értve ezen) már a transzformáláshoz szükséges infrastruktúra is elengedhetetlen, azaz aránytalanul megnőnek a költségek. Ráadásul egy „magán” hálózat esetében a meghibásodás elhárítása is nagy fajlagos költséggel jár. Összességében az ilyen megoldások csak ott tűnnek hatékonynak, ahol az országos hálózatokhoz való csatlakozás nem oldható meg. Ezeknek a területeknek viszont kiváló lehetőséget biztosítanak a megújuló energiák, így például a magashegyi területeken a függőleges tengelyű szélturbinás kisrendszerek (Riegler 2004).

A helyi szint ebben a vonatkozásban tehát nem releváns, pontosabban fogalmazva önálló, autonóm rendszerként nem hatékony megoldás. Mindig is az energiaellátási rendszer része volt a helyi szint, azonban ez idáig egyfunkciós szereplőként, azaz fogyasztóként jelent meg, míg az új összefüggésben komplex szerepet kap. Vajon ez már indokolttá teszi, hogy tervezési, irányítási szerepet is kapjon a helyi szint (Florini 2009; Goldthau, Sovacool 2012)? Ha igen, akkor ez az energiarendszerek irányításának decentralizálását jelenti a gyakorlatban (szakpolitikai irányítás értelmében). Ehhez azonban nem áll rendelkezésre megfelelő emberi erőforrás, intézményrendszer, tervezési kultúra. Ha tehát ez a sajátos szerep nem tölthető be megfelelő módon, akkor meg kell vizsgálni, hogy van-e olyan diszciplína vagy gyakorlati tevékenységcsoport, amelybe az energiapolitika sajátos kérdései integrálhatóak - az országos és a nemzetközi szinteken kívül - regionális, határ menti, szubregionális és helyi szinteken. 


\section{Területpolitikai integráció}

Melyek a vizsgálandó témák?

- Az energiaszegénység egyre nagyobb tömegeket érintő kérdése, különösen a növekvő energiaárak vonatkozásában;

- az energiaárak változása és hatása a helyi, regionális gazdasági versenyképességre;

- az energiaárak növekedésének hatása a lakossági mobilitási lehetőségekre, az ellátórendszer esetleges „sűrítésének” szükségessége;

- az energiatermelő rendszerek hatása az élőhelyekre, madárpopulációkra, általában a környezetre;

- az energiatermelő rendszerek telepítésének építésügyi és urbanisztikai összefüggései;

- a versengő területhasználati módok közti egyensúly megteremtésének szükséglete, ahol a megújuló energiarendszerek új tényezőkként jelennek meg;

- a megújuló energiák hasznosításának egyéb gazdasági összefüggései, a munkahelyteremtésben (UKERC 2014), munkavállalók képzésében;

- a megújuló energiák hasznosításához kapcsolódó támogatási és kedvezményrendszerek kidolgozása;

- az országos és nemzetközi szakpolitikai döntésekben a helyi, regionális érdekek érvényesítése.

Szociálpolitika, foglalkoztatáspolitika, iparpolitika, környezetvédelem és környezetgazdálkodás, építésügyi és egyéb szakhatósági engedélyezési rendszerek, humánpolitika, vidék- és agrárpolitika érinti az energiarendszerek átalakulását. Fontos megjegyezni, hogy az új energiarendszerek térben szétszórtan helyezkednek el, változásukra az ingatlanár, a megfelelő infrastruktúra és a természeti adottságok egyaránt hatnak. Valójában a területpolitika lehet az a szakpolitikai terület, s ennek következtében a területi tervezés az a gyakorlati tevékenység, amely megfelelően kezelheti az energiarendszerek átalakulásának kérdését - természetesen nem helyettesítve az energetikai és rendszertervezési, üzemeltetési szakági tervezők inputját. Hozzá kell tenni, hogy a közlekedési, szociális és gazdasági beavatkozások egymást kiegészítő, adott esetben szinergikus hatásának lehetőségét is egyértelműen javítja a területi tervezés integratív jellege.

A területpolitikai integráció mellett szól, hogy a területi tervezés eleve multidiszciplináris, rendelkezik a gyakorlatban is a megfelelő társadalmi részvételi, partnerségi készségekkel és módszerekkel, holisztikus megközelítést alkalmaz, jól kezeli a különböző gazdasági és társadalmi csoportok érdekeinek összehangolását (Faludi 2010). Ugyanakkor felmerül a kérdés, hogy a területi tervezésnek ez idáig milyen a kapcsolata volt az energia kérdésével. Érdekes megjegyzést tett Rutherford (2014), megállapítva, hogy míg az energiapolitikát tanulmányozók rendszeresen foglalkoznak a városi kérdésekkel, addig ez fordítva nem mondható el, ugyanis a városfejlesztők és -tervezők mintha eleve adottnak tekintenék az energia kérdését. 
Forduljunk a területpolitika európai hálózati központjához, az ESPON-hoz, s vizsgáljuk meg, vajon a 2007-2013-as kutatási projektek között hogyan jelent meg az energia, a megújuló energiák kérdése!

Az európai szegénység és társadalmi kitaszítottság területi dimenziójával foglalkozó ESPON kutatás (The Territorial Dimension of Poverty and Social Exclusion in Europe, TiPSE) keretén belül megjelenik az energiaszegénység, de csak mint egy nem részletezett eleme a vizsgált szegénységi modelleknek (TiPSE 2012). A konvergenciarégiók sikerességi faktorait vizsgáló SEARCH projekt (Structured empirical analysis for convergence regions) keretén belül két szempontot említenek: a szélfarmok negatív hatását a tájra, valamint az olcsó elektromos áram szerepét a vállalkozások versenyképességében (SEARCH 2013).

Ugyanakkor az energiával, a megújuló energiákkal egyáltalán nem foglalkozik három meghatározó kutatási projekt: a SMART-IST (Institutional Capacity for Territorial Development), amely az intézményi kapacitásokat vizsgálja (SMART-IST 2012), az SGPTD projekt (Second Tier Cities and Territorial Development in Europe), mely a kisebb városok és a területi fejlődés témáját körvonalazza, illetve a területi irányítás javításával foglalkozó projekt (Towards Better Territorial Governance in Europe) is eltekint a kérdés vizsgálatától (SGPTD 2012).

Részletesen foglalkozik a megújuló energiákkal egy másik projekt a falusi régiók lehetőségeit kutatva (Potentials of Rural Regions, PURR) (PURR 2012). Az energiaszegénység kockázatával küszködő régiók (Regions at Risk of Energy Poverty, ReRisk) projektje kifejezetten azt elemzi, hogy a tagállami szint alatti energiakormányzás hozzájárul-e a fenntarthatóság javításához (ReRisk 2010). Több esetet is megvizsgál, bemutatva, hogy hogyan alakult ki egyes régiókban a civil mozgalomból, gazdasági érdekből, politikai akaratból az energia kormányzása. A ReRisk szerint az energiaszegénység elleni küzdelemben, a megújuló energiák hasznosításának elterjesztésében, a megfelelő energiapolitika kialakításában meghatározó, sok esetben az optimális döntési szint a helyi és regionális szint. Ugyanebbe az irányba mutat a North Sea STAR program (Spreading Transnational Results), amely az északi-tengeri energetikai együttmüködés sajátos kormányzási, tervezési megoldásait teszi közzé a többi régió szakemberei számára (North Sea STAR 2013).

A megfelelő ESPON-kutatások vázlatos áttekintése alapján elmondható, hogy jellemzően csak azok a kutatási projektek foglalkoznak az energia, a megújuló energiák kérdésével, amelyeknek ez a közvetlen témája, azonban Európában az általános területi tervezéssel, területi folyamatokkal kapcsolatos vizsgálódásoknak az energia és a megújuló energiák nem kiemelt szempontjai.

Márpedig bőven lenne tennivaló, mivel a következő, 2020 utáni, 2030-as EU-s stratégiai célkitűzések megfogalmazásakor eleve a tagállamok sokféleségét veszik figyelembe, a tagállamokra bízva, hogy milyen célokat tűznek ki, hogyan járulnak hozzá az európai szintű célkitűzésekhez. Többször elhangzik ezen a téren is a többszintű kormányzás fogalma (Lindstrom 2011; Smith 2007), de mivel az ener- 
gia nem átruházott hatáskör, az Európai Unió itt csak annyiban dönthet, amennyiben környezetvédelmi, s így energiahatékonysági vagy klímaváltozási szabályokat alkot, illetve részben hivatkozik arra, hogy az uniós beavatkozást az indokolja, hogy a tagállamok külön-külön nem képesek megfelelően hatékony lépéseket tenni ezen a téren. Nyilvánvaló, hogy nem az a helyes kérdés, hogy szükség van-e többszintü kormányzásra az energiapolitika terén, hanem az, hogy ez kiemelt szempont legyen, vagy a területi tervezés gyakorlatába integráltan jelenjen meg. Utóbbi mellett nem csak hatékonysági érvek szólnak.

Azt gondolom, hogy az eddigiekben már megfelelően bemutattuk, hogy korunkban az energia nem valamilyen külső szempont a területi folyamatok alakulásában, hanem a helyek, térségek, régiók maguk is az energiarendszerek aktív alakítóivá váltak. Ezen túlmenően olyan viták is előtérbe kerülnek, mint amelyek a mezőgazdasági területek energiatermelésre való átállítása vagy az erdővagyon „zöld” megújuló energiaként való felhasználása kapcsán zajlottak Európa egyes térségeiben.

A vonatkozó szakirodalom elsősorban német és brit példákat vizsgál. Kiemelten kell megemlítenünk Monstadt (2007) sokszor hivatkozott és úttörő (Truffer, Coenen 2012) tanulmányát az energia- és klímapolitika berlini átalakulásáról, amelyben bemutatja, hogy a szövetségi köztársaságban miként alakul át ezekben a témákban a kormányzás: az irányító, tulajdonosi szerepben levő, támogatásokkal operáló, szinte kizárólagos finanszírozóként fellépő közszféra hogyan megy át képlékeny, nem tulajdonosi, esetleg ellenőrző, de inkább tudatos partneri szerepkörökbe. Monstadt kiemeli a „zöld” vállalkozók (ecopreneurs) szerepét is ebben a folyamatban, akik egyszerre szereplők, illetve a szakpolitikai célok kedvezményezettjei. Monstadt is hangsúlyozza, hogy az átmeneti idöszakban az új kormányzási forma költségesebb, mint az előző. Ha ehhez hozzávesszük azt, hogy 2020-2030-ig az előrejelzések szerint a zöldenergiás beruházásoknak (European Commission 2013b), valamint az energiarendszerek adaptációs költségeinek tulajdoníthatóan növekedni fognak az energiaárak, azt is hangsúlyozni kell, hogy a műszaki-pénzügyi kiadások mellett a kormányzási költségek is növekedni fognak.

Az Európai Bizottság egyik tanulmánya (European Commission 2013a) arra is rámutat, hogy a területfejlesztésnek elő kell segítenie a társadalmi integrációt, annak érdekében, hogy kevésbé legyen hierarchikus, felülről vezérelt, alakuljanak ki az együttműködési hálózatok, illetve partnerségek. Bunning (2013) szerint meg kell vizsgálni, hogyan irányíthatók helyesen az új energiarendszerek, milyen partnerségekre van szükség, s kifejezetten fontos helyi, regionális feladatként jelöli meg a fosszilis energiahordozóktól mentes fejlődés üzleti, gazdasági modelljének kidolgozását.

A helyi lehetőségek példáit sorolja a szakirodalom. Hawkey (Hawkey et al. 2013) az Egyesült Királyságban kialakult ún. LEGO (helyi energiakormányzás és energiaszervezet) elméleti kereteit dolgozta ki, kiemelten kezelve a társadalmi tőkét mint kulcstényezőt. Parag (Parag et al. 2013) az alacsony szénfelhasználású 
közösségi csoportokat mint az energiakormányzás új szereplőit vizsgálta, kiemelve a közösségi cselekvésben rejlő tanulás lehetőségét. Smith (2007) tanulmányában már korábban felhívta a figyelmet az ún. „angol regionalizmusra”, amely kiterjed az energiatermelés és -felhasználás vonatkozásaira is. Lényege, hogy a központi kormányzás magában foglalja a regionális szintet is a célkitűzések meghatározásával és területi lebontásával. Smith $(2007,6280$.) felhívja a figyelmet arra, hogy „a regionális megújuló energia kormányzási tevékenységeket katalizált a régiókban, amelyet nem szabad összetévesztenünk a kiterjedt befolyással."

\section{Összegzés}

Jelen tanulmányban röviden áttekintettük az energiaszektor változási tendenciáit területi összefüggésükben, illetve arra kerestük a választ, hogy a területi tervezés folyamatába illesztendő-e, illeszthető-e az új energiapolitika helyi és regionális szintje. Kerestük a választ a szakirodalomban, ahol az energiaszektorral jellemzöen technológiai, energiapolitikai kérdésként vagy a területi tervezés speciális szűk területeként foglalkoztak. A kérdés vizsgálata alapján azonban arra a következtetésre jutottunk, hogy kifejezetten hatékony megoldás lehet az energiapolitikai kérdések integrálása az amúgy is holisztikus, kollaboratív, partnerségekre alapozó (Faludi 2010; Healey 2006) területi tervezési gyakorlatba.

Ezzel természetesen nem állítjuk, hogy a technológiai megközelítés elvetendő volna. Ellenkezőleg: több szakértelmet, technológiai ismeretet követel a területi tervezés az energiatermelés és -felhasználás terén is. Az új értelmezés ideális lehetöséget nyújt arra, hogy kísérletet tegyen a területi tervezés a posztmodern tervezéselmélet (Faragó 2005; Haughton et al. 2010) és az aktuális energetikai, klímaváltozási kontextus eszközeinek együttes alkalmazására.

\section{Köszönetnyilvánítás}

A kézirat az MTA Domus Szülőföldi senior ösztöndíj keretén belül készült, a pályázat címe: „Térségi és regionális energiapolitika: modellalkotás".

\section{Irodalom}

Boyle, G., Everett, B., Morris, D., Scurlock, J., Ramage, J., Elliott, D., Taylor, D., Duckers, L., Garnish, J., Brown, G., Alexander, G. (2012): Renewable energy. Power for a sustainable future. Oxford University Press, Oxford 
Bunning, J. (2013): Governance for regenerative and decarbonised eco-city regions. Renewable Energy, 37., 628-635. http://doi.org/827

Delina, L. (2012): Coherence in energy governance. Energy for Sustainable Development, 4., 493-499. http://doi.org/828

European Commission, (2013a): Study on promoting multi-level governance in support of Europe 2020. Publication Office of the EU, Luxembourg

European Commission, (2013b): Trends to 2050. Reference scenario 2013. Publication Office of the EU, Luxembourg

Everett, B., Peake, S., Boyle, G., Ramage, J., Crabbe, D., Elliott, D., (2012): Energy systems and sustainability. Power for a sustainable future. Oxford University Press, Oxford

Faludi, A. (2010): Cohesion, coherence, cooperation: European spatial planning coming of age? Routledge, London

Faragó L. (2005): A jövőalkotás társadalomtechnikája. Dialóg Campus, Budapest, Pécs

Florini, A., Sovacool, B. (2009): Who governs energy? The challenges facing global energy governance. Energy Policy, 12., 5239-5248. http://doi.org/fv8swh

Gasch, R., Twele, J. (eds.) (2012): Wind power plants. Fundamentals, design, construction and operation. Springer-Verlag, Berlin

Goldthau, A., Sovacool, B. (2012): The uniqueness of the energy security, justice, and governance problem. Energy Policy, 41., 232-240. http://doi.org/b2dx57

Haughton, G., Allmendinger, Ph., Counsell, d., Vigar, G. (2010): The new spatial planning. Territorial management with soft spaces and fuzzy boundries. Routledge, London

Healey, P. (2006): Collaborative planning. Palgrave, New York

Hawkey, D., Webb, J., Winskel, M. (2013): Organisation and governance of urban energy systems: district heating and cooling in the UK. Journal of Cleaner Production, 1., 22-31. http://doi.org/829

Jenssen, T., König, A., Eltrop, L. (2014): Bioenergy villages in Germany: Bringing a low carbon energy supply for rural areas into practice. Renewable Energy, 61., 74-80. http://doi.org/83b

Lindstrom, N. (2011): Power trips: Europeanization, market-governance, and energy policy in the Western Balkans. Policy and Society, 3., 197-207. http://doi.org/fwv9km

Monstadt, J. (2007): Urban governance and the transition of energy systems: Institutional change and shifting energy and climate policies in Berlin. International Journal of Urban and Regional Research, 2., 326-343. http://doi.org/fn6h9n

North Sea STAR (2013): Spreading transnational results. Interim report. ESPON, Luxembourg

Parag, Y., Hamilton, J., White, V., Hogan, B. (2013): Network approach for local and community governance of energy: The case of Oxfordshire. Energy Policy, 62., 1064-1077. http://doi.org/83c

PURR (2012): Potentials of rural regions. Final report. ESPON, Luxembourg

ReRisk (2010): Regions at risk of energy poverty. Final report. ESPON, Luxembourg

Riegler, H. (2004): HAWT versus VAWT: Small VAWTs find a clear niche. Refocus, 4., 44-46. http://doi.org/dmtc3v

Rutherford, J., Coutard, O. (2014): Urban energy transitions: Places, processes and politics of sociotechnical change. Urban Studies, 7., 1353-1377. http://doi.org/83d

SEARCH (2013): Structured empirical analysis for convergence regions: identifying success factors for consolidated growth. Final report, Version 2. ESPON, Luxembourg

SGPTD (2012): Second tier cities and territorial development in Europe: Performance, policies and prospects. Final report. ESPON, Luxembourg

Simon, S., Wiegmann, K. (2009): Modelling sustainable bioenergy potentials from agriculture for Germany and Eastern European countries. Biomass and Bioenergy, 4., 603-609. http://doi.org/c3rrns

SMART-IST (2012): Institutional capacity for territorial development. Final report. ESPON, Luxembourg

Smith, A. (2007): Emerging in between: The multi-level governance of renewable energy in the English regions. Energy Policy, 12., 6266-6280. http://doi.org/d284qk

Sovacool, B. (2011): An international comparison of four polycentric approaches to climate and enegry governance. Energy Policy, 6., 3832-3544. http://doi.org/ctxxdp

Sterner, M., Fritsche, U. (2011): Greenhouse gas balances and mitigation costs of 70 modern Germany-focused and 4 traditional biomass pathways including land-use change effects. Biomass and Bioenergy, 12., 4797-4814. http://doi.org/bqm4qz 
TiPSE (2012): The territorial dimension of poverty and social exclusion in Europe. Interim report. ESPON, Luxembourg

Truffer, B., Coenen, L. (2012): Environmental innovation and sustainability transitions in regional studies. Regional Studies, 1., 1-21. http://doi.org/fzkqn9

UKERC (2014): Low carbon jobs: The evidence for net job creation from policy support for energy efficiency and renewable energy. UK Energy Research Centre, London 
$\frac{1}{2}$ 